\title{
CONSUMER PROTECTION IN DIGITAL ECONOMY ERA : LAW IN INDONESIA
}

\author{
Author: Sinta Dewi Rosadi and Zahra Tahira \\ Origin of Author : Faculty of Law, University of Padjadjaran \\ Email: sinta@unpad.ac.id
}

\begin{abstract}
Developments in information and communications technology have significantly influenced and changed lives of peoples by providing new opportunities for consumers and businesses. In digital economic era, an increasing number of consumers engage in e-commerce, which provides easier and faster access to products and services However it also presents some challenges for consumers that differ from offline commercial transactions. The impersonality of e-commerce weakens the relationship between businessman and consumers, thereby increasing consumer vulnerability that could lead to to unfair commercial practices and causing uncertainty and lack of trust by consumers. Therefore, there is a need by the government and businessman to promote and protect consumer trust in digital markets so it will not hamper development digital economy
\end{abstract}

Keywords: Consumer, Digital Economy

\section{A. INTRODUCTION}

At the present the world have entered the digital economy era where both individuals and organization use technologies to conduct their activities. According to statistical data released by APJII (Association of Internet Service Providers Indonesia) shows that internet users in Indonesia has increased in 2017 reached the number of 132.7 million users or about 51.5 percent of the total population of Indonesia amounted to 256.2 million (Data Pengguna Internet di Indonesia ( Data for Internet Users in Indonesia) $2016 \mathrm{http} / /$ web.id/tag/2017/ (accessed on January 10, 2018).

These developments has changing the way business is conducted further in the data analysis report by Ernst \& Young shows that the growth in the value of online business sales in the country each year increased by 40 percent. This data indicates that digital economy began to move and grow rapidly in Indonesia and the shift toward digital transaction will contribute to the potential economic growth in In Indonesia. 
The digital economy has provide several benefits for consumers, as follows (E-commerce and Consumer Protection, http://unctad.org/ ( accesses , Januari 10, 2018):

a. The internet with high-speed capacity has provided consumer with great variety of product that being offered online;

b. Product innovation has provided consumer a wider range of products and services;

c. Consumer also have an easy to use payment mechanism ;

d. Growing use of mobile devices and application which made easier for consumer to shop.

In addition to the potential benefits and expected economic growth in the digital economy there are also some vulnerability for consumer protection due to the complex relationship between business and consumers because the business procedures are very different from conventional businesses. For example, in the data privacy perspectives the problem for consumer protection is how the businesses will processing data privacy of the consumer such as processing the data includes collection, recording, storage, adaptation, disclosure, transmission (Ian J Lyod, 2014: 52).

\section{B. PROBLEM STATEMENT}

Lack of trust could lead to uncertainty of consumer in digital economy and consumer protection play an important role to enchance the growth of digital economy

\section{RESEARCH METHODS}

Based on the data that used and the nature of the juridical-normative research in this research applied statute approach. Data analysis conducted in qualitative technique by legal interpretation and synchronization of the provisions of the related law. Data gathering collected by library research to select the important part of Law on the consumer protection in digital economy

\section{DISCUSSION AND RESEARCH RESULT}

\section{D.1. Consumer Protection}


Walter Brenner stated that digital economy is an aggressive use of data by transforming business models, facilitating new products and services, creating new processes, generating greater utility, and ushering in a new culture of management. So there has been transformation of how to do business by utilizing information technology in the field of economy globally that causing changes in the level of productivity and growth or many who call the term New Economy (Economy Digital, http://searchcio.techtarget.com/definition/digital-economyEconomy, accessed on Juny 2017)

As a result, a new society has emerge called information society or knowledge society and through the advancement of ICT, the utilization of factors of production changes from the physical such as land, labor, money becomes nonphysical through digital plus through creativity and technological innovation and named as disruptive innovation that helps create new markets, disrupt or destroy existing markets, and ultimately replace the previous technology. Disruptive innovation develops a product or service in an unexpected way the market, generally by creating different types of consumers in new markets and lowering prices on the old market (Four Factor of Disruptive Theory , https://www.kompasiana.com/ronaldwan/ ( accesses December 1, 2017). One of the main problem in e-commerce is consumer protection because businesses and consumer does not meet physically so there are no personal interaction, no customer services representation (Michael L. Rustad, 2009: 195).

In Digital economy, consumers have several advantages such as fast access to transactions anywhere and anytime, many choices of different types of products by comparing prices quickly while bosses the seller can make the chain of trade more efficient because the cost for marketing and promotion is lower and can expand market faster. According to the OECD report there are several advantages of the digital economy era to consumers (OECD Guideline for Consumer Protection in E-Commerce, 1999):

a. Digital networking and communication infrastructures provide a global platform and producing higher quality goods and better services because the product can be ordered, viewed and selected first and the competition among players will be sharper with the extension of rating system so that business will be faster to change the model in order to find consumers as much as possible.

b. Higher goods and better services being offered using ICT mechanisms because the product can be ordered, viewed and selected first and the competition among players will be sharper with the extension of rating system so that business will always adapt to and change the model in order to make a new consumers as much as possible. 
c. Consumer by utilizing technology more convenience in getting service and can choose which platform is needed

d. Consumers can easier to choose products that are available and accessible globally

e. The relationship between services provider and consumer more personally.

While consumers are increasingly prefer digital technology, online transaction still have many problems from consumer protection perspectives due to different characteristic from the conventional business where the interaction between the seller and the buyer is not direct and the physically purchases changed with visual purchase with the image on the computer screen or mobile phone therefore the information and description of the items to be purchased becomes very important.

In addition to the digital economy that using online media for marketing can be through social media such as face book, twitter or instagram so that advertising costs can be reduced to cheaper but with the risk of using direct marketing by accessing consumer data without the knowledge of consumers. The way Digital economy payments also use online mechanisms that require understanding and thoroughness of consumers. Because there are several factors above that distinguish between digital economy and conventional business. One of the main problems is there are no physical clues in e-commerce that affect consumer sense of trust and make it more difficult to establish consumer trust (Malin Gustavsson, 2006).

hence there are some risk of consumer protection in digital economy as follows:

a. Information and Transparency in digital relating to corporate identity will create trust in digital economy trust is an important factor so the consumer must get accurate information about the company's location, its legal entity and its activity;

b. The vendor must give clear information relating to Corporate Identity In digital economy trust is an important factor so that the consumer must get correct information about the company's location, its legal entity, its activity;

c. Consumers should obtain all information relating to the good products and services offered so that they can choose products that suit their needs; 
d. In digital transactions the security factor of the system and the protection of consumer personal data becomes of particular importance considering the involvement of electronic systems that can easily be corrupted by viruses and the extent to which the protection of consumer personal data will be maintained by the seller;

e. Consumers should receive education and socialization so that they are aware of their rights, especially in the digital economy which for most consumers is still new.

\section{D.2. Consumer Protection According to Law Number 8 of 1999}

Concept of Consumer Protection in Indonesia is regulated by Law Number 8 of 1999, the Law applies some basic concept of consumer protection namely:

a. Product safety

b. Entrepreneur Behavior

c. Advertising Procedures

e. Establishment of Consumer Protection Agency

f. Dispute resolution

\section{D.3. Law Number 8 of 1999 concerning Consumer Protection and Digital economy}

Law Number 8 of 1999 in Article 4 has regulated the rights of consumers covering;

1) Right to comfort, security and safety in using and consuming goods and / or services.

2) The right to choose and obtain goods and / or services in accordance with the exchange rate and the conditions and promised warranties.

3) Right to the right, clear and honest information about the condition and guarantee of goods and / or services.

4) The right to be heard of opinions and complaints on goods and / or services used.

5) The right to secure advocacy of protection, and to appropriate dispute resolution of consumer protection. 
6) Right to get training and consumer education.

7) The right to be treated or served properly and honestly and not discriminatively.

8) Right to get compensation, indemnification and / or reimbursement, if the goods and / or services received are not by agreement or not as they should be.

9) The rights set forth in the provisions of other laws and regulations.

Some of the above provisions can still be applied in e-commerce, among others, The right to comfort and safety in consuming goods and / or services set forth in Article 4 (1) is still relevant considering consumers directly identifying, viewing and touching the items to be ordered over the internet, as is common in face-to-face transactions in the marketplace. In addition, the right to obtain security in digital transactions in Indonesia is not enough to remember still lack of data security guarantee, credit card numbers, adequate passwords provided by traders residing in Indonesia, such as cryptographic techniques.

The new government launched the digital reliability certification in 2016 digital certificates is a file used to identify a person or entity on a network like on the internet. Digital certificates are also safe, because communication between two devices uses data encryption. An analogy about digital certificates when they want to leave the country requires a passport to enter a country. Passport is a tool for establishing identity in order to enter a country. Digital certificates provide identical identification to the electronic world. Certificates are issued by the Certificates Authority (CA). CA has almost the same role as the passport service office. The role of a $\mathrm{CA}$ is to certify the holder of the identity of the certificate and to enter so the certificate cannot be damaged. Once CA marks a certificate, the certificate holder can file it to people, pages, and network resources to prove his identity and has been encrypted, this is still a discourse because it is still not established institution and standard procedure implementation that cannot be used to ensure security to consumers.

Furthermore in Article 4 (2) the consumer is entitled to the right information, clear and honest about the condition of a good. This is because business actors and consumers do not meet directly and communication occurs if the consumer is actively asked to business actors. In this case the information about the product is very less at all because in doing the merchant's offer only show the product description and product image on the website only. There are goods traded on the internet that require more than just product descriptions. 
There are several consumer protection issues that are still the duty of the policy makers and have not been accommodated in the Consumer Protection Act, among others :

\section{D.4. Internet Access Problems}

One of the most important consumer rights in the digital economy is access to the internet and must be provided by the government. This is in line with the 9 th Sustainable Development Goal objective which is the common goal of the countries until 2020, which is access to the widest possible information so as to provide cheaper, faster service at an affordable price. In Indonesia the problem of internet infrastructure is still a constraint so that there is still digital divide or digital divide is always associated with the difference between access and use of information and communication technology (ICT), caused by imbalance and difference due to imbalance of ICT growth. The problem of digital divide in Indonesia is much influenced by the uneven distribution of information and communication infrastructure and supporting regulations in various regions. The serious obstacle facing the government to overcome the digital divide lies in the way people view the use of information and communication technology, so the government needs to convince and train the community that the use of ICT can increase productivity, employment, and availability of information quickly and easily used in various aspects of the field life.

One of the most important consumer protection principles is consumers get information because by not providing the right information will lead to consumer disbelief and ultimately encourage market failure or market failure. Information that must be provided to the consumer include information about the product, product usability, side effects on product use, expiry date. Besides, the information about the identity of the producer, the location of his business forms a seat in the digital economy because the consumer is located in another country so it is very difficult to physically examine, the service, the terms and conditions so as to enable the consumer to make the correct choice when going to buy a product.

\section{D.5. Manufacturers Must Guarantee For Products Defect}

Product liability has become a major concern in the discussion of consumer protection and has not been maximally regulated in the Consumer Protection Act, especially in the digital economy. Its protection is becoming increasingly important given the online transaction mechanism that is non-physical so it is difficult for consumers to be able to monitor whether goods purchased defect is not an example in the case of Samsung Galaxy Note7 that exploded has caused consumer concerns 
over the security of the product in addition to the widespread sale of health products such as supplements, vitamins and even drugs sold online with the concept of ehealth.

\section{a. Protection of Consumer Personal Data}

In cross-border transactions through online it is very important to pay attention to the extent to which consumers are accessible to personal advocates of ICT. The problem of protecting consumer's personal data will also appear in the payment mechanism in particular: i) how to determine the party responsible for the use and management of consumer payment information; ii) Identification of the parties must not be able to use anonymous identity; iii) how such payment information should be maintained and not disseminated to third parties.

In cross-border transactions through online it is very important to pay attention to the extent to which consumers can be privately protected because now almost all online transactions always access consumer personal data for marketing and advertising purposes through various ICT advances. The problem of protecting consumer's personal data will also appear in the payment mechanism in particular: i) how to determine the party responsible for the use and management of consumer payment information; ii) Identification of the parties must clearly not be able to use anonymous identity; iii) how such payment information should be maintained and not disseminated to third parties.

\section{b. Dispute Settlement Mechanism}

In resolution of digital economy dispute people often use the term ODR or also known as Online Dispute Resolution is a way of dispute resolution conducted through the internet media, in the sense that the process of completion is done by the parties who are in a cross border territory without having to meet advance. Basically, ODR is like any other conventional dispute settlement, the difference lies in its medium using the Internet (International Network) media. ODR is included in the ADR, where ADR has 3 (three) types of dispute resolution, namely negotiation, mediation and arbitration. In Indonesia, ODR has not been utilized properly given the need for a technological understanding to implement it both from the side of the seller and the consumer when the benefits are very large to resolve disputes quickly, effectively and inexpensively.

\section{c. The Consumer Law Protection Model in Digital economy}


Law Number 8 of 1999 is no longer appropriate in providing legal protection in digital economy and must be updated immediately by applying a comprehensive regulatory model taking into account the digital economy architecture with regard to juridical and non-juridical factors.

\section{The Legal Aspects}

a. The validity of the agreement as set forth in Article 1320 of the Civil Code has been unable to cover the digital economy because between producers and consumers do not meet physically so that in practice it will be difficult to determine whether agreement has occurred or whether at the time the message was sent, payment or when goods have been shipped so that it needs to be regulated in more detail to protect consumers especially for cross border transactions.

b. The arrangement of standard clauses which is a practice that is always used in the digital economy because the principals do not meet face to face so that the terms of the contract is determined unilaterally by the seller and often weakens the consumer's position because the consumer is not given the mechanism to make the choice to change the agreement known as terms take it or leave it so the choice for consumers only accept or refuse to make transactions. It needs to be regulated more specifically how this standard contract is implemented in a digital transaction.

c. need to be regulated in more detail how the protection of consumers, especially consumers who have not understood both legally and technologically.

d. The absence of a third party institution as a guarantor of the identity. Usually an institution that verifies digital certificates or digital signatures to ensure ownership of a digital identity. Digital signature is a code using cryptography technology. An important function of this institution is to prevent frauds that can occur when

e. Manufacturers' guarantees of product defects or product liability are inadequate, especially for digital transactions because cross-border types of activities will deal with the various legal systems governing product defects, especially now that almost all goods can be purchased through online transactions. Legal issues will arise how to monitor the flow of in and out of medical products that can be traded directly without being supervised by the government.

f. Another issue that has not been regulated in the Act is the extent to which the seller will protect the consumer's personal data which is the right of privacy that should be protected that can be accessed by the seller at the time the buyer will make the transaction by providing his personal data. The digital personal data 
regime is now internationally strictly regulated and apply several principles that ensure the protect the processing of consumer personal data

\section{Non Legal factors that require special attention are;}

\section{a. Security in transactions}

The security of transactions is absolutely necessary to ensure consumer safety of consumer personal data such as information on credit card numbers, password numbers or other personal identities of misuse by unauthorized persons. According to the findings of Norton Cyber security Insight Report, the average of cyber users lost globally nearly US \$ 358 per person or about a total of US \$ 150 billion per year. From the study obtained in 17 countries shows that cybercrime has increased and Indonesia is among the most vulnerable countries of cyber crime (The Impact of of Cyber, http://mastel.id/kerugian-akibat-cyber-crime/ ( accesses, November, 2017). There are still many sellers through digital systems in Indonesia and the consumer who has not understood the importance of maintaining security in digital transactions. An acceptable level of information security in a digital economy is absolutely necessary.

The information security system has four very basic purposes, namely (Alan Davidson, 2009: 268):

\section{i. Confidentiality}

Ensure whether the information sent by the system and technology can be guaranteed confidentiality and cannot be interrupted, disclose by others who are not eligible. Especially for the most important data, it takes a very high level of confidentiality, which is only accessible to certain people.

\section{ii. Integrity}

Ensure the integrity and consistency of the data in accordance with the original, so that can prevent from people who are not responsible for duplication and data destruction

\section{iii. Availability}

Ensure data availability for legitimate users to access their own information and resources. Considering that one characteristic of a digital economy that is not physically visible is very different from the conventional trading mechanism by which the seller and buyer meet, the traded item is negotiable, the consumer can simply touch the item he wants to buy and everyone can do it. This is because in operating the Internet requires enough intellect to understand it. In addition, the internet network also has not penetrated to the remote villages. 


\section{iv. Education and Socialization is required for all Parties}

One of the main factors that become the weakness of consumers both conventional and in digital economy is the lack of awareness of the consumers rights especially the element of education is still low specifically in the digital era that requires a minimal capability in the of computing. In this case the responsibility for education and socialization is not only the responsibility of the government but also the responsibility of the merchant for his business to grow as well as other nongovernmental institutions (Ahmadi Miru and Sutarman, 2015: 185).

\section{E. CLOSING}

In the digital economy the era consumer trust is one of important factor be considered by businesses because without the consumer trust then digital transforms that will encourage economic growth of a country will not be achieved thus both government and business are needed to promoting trust and confidence in digital economy ecosystem. The Government of Indonesia itself has submitted the target of digital economic growth until 2020 and one of the problems that has to be establish by government is how to provide protection to consumers in digital economy so that will foster the trust of domestic and global communities to take advantage of Indonesia's digital economy because the Indonesia Consumer Protection Law has not been able to provide adequate protection for consumers in the era of digital economy and required revisions by accommodating digital economies

\section{BIBLIOGRAPHY}

\section{BOOKS}

Ahmadi Miru \& Sutarman Yodo, 2015, Consumer Protection Law, Radja Grafindo Persada: Jakarta.

Davidson, Alan, 2009, The Law of Electronic Commerce, Cambridge University Press: Australia.

Husni Syawali and neni Sri Imaniyati (ed), 2000, Consumer Protection Law, CV Mandar Maju: Bandung.

Llyod, J, Ian , 2014, Information Technology Law: Oxford University Press, Oxford. 
Rustad, L, Michael , 2009, Internet Law, Thomson Reuteurs, St Paul, Minnesota.

\section{PAPER:}

Bagus Hanindyo Mantri, 2015, Legal Protection Against Consumers In E-Commerce Transaction, Paper.

Gustavsson, Malin, 2006, Commerce Trust in E-Commerce, Department of Business Studies, Paper, Sweden..

Report of the Ministry of Justice and Consumer Protection of Germany, 2017, Indicators of consumer protection and empowerment in the digital world,.

\section{INTERNET:}

List of Successful Digital Indonesia Entrepreneurs, http://goukm.id/daftar-9- pengusaha-sukses-bad-technology-digital/Being Banned Foreign Digital Players Government Must Support the Local Star-Up, http://industri.bisnis.com/ $\mathrm{read} / 20171102 / 12 / 705420 /$ (accessed November 20, 2017)

Economy Digital, http://searchcio.techtarget.com/definition/digital-economyEconomy, (accessed December 2nd, 2017)

Four Things about Disruptive Theories that are often forgotten, https://www.kompasiana.com/ronaldwan/ (accessed December 1, 2017)

International Law and Consumer Protection: The History of Consumer Protectionat http://www.nyulawglobal.org/globalex/International_Law_Consumer_Protection.html, (accessed November 10, 2017)

Report of ApJI (Association of Indonesian Internet Service Entrepreneurs https://apjii.or.id/downfile/file/PROFILPENGGUNAINTERNETINDONESIA2014. pdf, (accessed December 1, 2017)

OECD Report on the Guide of Consumer Protection, 2016

Consumer Protection in the Digital Economy Era Mansih Minim, http://www.hukumonline.com/berita/baca/1t58c911a11aeef/ (accessed December 10, 2017)

Source accessed from kominfo website, Indonesia Will Become South East

Asia's Largest DigitalPlayer, https://kominfo.go.id/index.php/content/detail/6441/Indonesia $+\mathrm{A}++\mathrm{Jo}+$ Play+Economy+Digital+Large + on + Asia

+ Southeast / 0 / berita_satker, downloaded on 12 years 12 hours 8.00 am

WhatisDigitalEconomy, https://www2.deloitte.com/mt/en/pages/technology/articles/mt-what-is-digital-economy.html (diskses December 10, 2017) 
Cyber Crime Involves Losses USD 150 Billion Dollars Each Year, http://mastel.id/ kerugian-akibat-cyber-crime/ (accessed November 30, 2017) 